\title{
INTEGRATED FRUIT PRODUCTION (IFP) FOR NEW ZEALAND PIPFRUIT: EVALUATION OF PEST MANAGEMENT RECOMMENDATIONS
}

\author{
J.T.S.WALKER ${ }^{1}$, C.H. WEARING ${ }^{2}$, S.J. BRADLEY ${ }^{1}$, \\ P.W. SHAW ${ }^{3}$, G.M. BURNIP ${ }^{4}$, A.R. TOMKINS ${ }^{5}$, \\ C.A. RICHARDSON ${ }^{6}$ and A.J. HODSON ${ }^{7}$
}

\author{
The Horticulture and Food Research Institute of New Zealand Ltd. \\ ${ }^{1}$ Hawkes Bay Research Centre, Private Bag 1401, Havelock North \\ ${ }^{2}$ Clyde Research Centre, RD 1, Alexandra \\ ${ }^{3}$ Nelson Research Centre, PO Box 220, Motueka \\ ${ }^{4}$ Canterbury Research Centre, PO Box 51, Lincoln \\ ${ }^{5}$ Ruakura Research Centre, Private Bag 3123, Hamilton \\ ${ }^{6}$ ENZAFRUIT New Zealand (Int.), PO Box 1011, Hastings \\ ${ }^{7}$ Taylor, Pinchin and Associates Ltd., PO Box 55, Hastings
}

\begin{abstract}
Approximately 370 apple growers in seven districts participated in the implementation of an Integrated Fruit Production (IFP) programme during the 1997-98 season. Pest management was based on monitoring and threshold-based applications of selective insect growth regulator and organophosphate insecticides. Post-bloom insecticide use across all regions ranged from 2.4 - 4.1 applications on Gala apples to 3.0 - 5.8 applications on the cultivar Braeburn. Average levels of codling moth and leafroller damaged fruit across all regions were low and ranged from $0-0.06 \%$ and $0.01-0.73 \%$ respectively. Mealybug and scale were important pests and infestation ranged from $0-0.40 \%$ and $0.01-2.90 \%$ respectively. Revised IFP recommendations for leafroller control provided acceptable fruit quality, but further revision is required to improve scale and mealybug control.
\end{abstract}

Keywords: integrated fruit production, apple, pest management, tebufenozide.

\section{INTRODUCTION}

New Zealand Integrated Fruit Production - Pipfruit (NZ IFP-P) is a new approach to pipfruit production which targets consumer concerns over the impact of crop production practices on the environment (Batcheloret al. 1997). The pest management philosophy embodied in integrated fruit production (IFP) requires greater emphasis on the use of biological control, pest thresholds, minimal use of broad-spectrum pesticides and replacement with selective products. A pilot IFP programme was first tested with 88 growers in the 1996-97 season. This produced crops with low pest incidences, but adjustments to pest thresholds and monitoring procedures were required to prevent unforeseen crop loss and high monitoring costs (Walker et al. 1997).

The key pests of New Zealand's apple crop are codling moth (Cydia pomonella) and leafrollers. In the pilot programme laborious shoot and fruit inspections were used to determine leafroller control decisions but, in 1997-98, this was replaced by a pheromone trapping programme based on cumulative moth catch between sprays (Bradley et al. 1998). This was designed to allow wider adoption of the IFP programme by growers and improve the reliability of leafroller control decisions. Minor revisions to pest thresholds for mealybug and scale insects, based on pest management outcomes from the 1997 season (Walker et al. 1997) are given in the ENZAFRUIT New Zealand Integrated Fruit Production Pipfruit Manual (Anon. 1997). 
As the IFP programme for pipfruit expands, it is essential to improve its reliability and simplicity for uptake by fruit growers. It is important to ensure that a high proportion of fruitgrowers in each of the major fruit growing regions produce crops without serious pest outbreaks. In particular, we need to ensure that growers suffer no economic loss or incur pest levels which exceed phytosanitary tolerances for export crops. This paper evaluates insecticide use, fruit damage and pest issues associated with expansion of this programme as implemented in the 1997-98 season.

\section{METHODS}

In the 1997-98 season, 370 orchards were registered with ENZAFRUIT for the IFP programme. Orchards were from Waikato (37), Gisborne (37), Hawkes Bay (163), Wairarapa (22), Nelson/Marlborough (57), Canterbury (12) and Central Otago (42). Growers were asked to follow the revised programme published in the ENZAFRUIT NZ IFP-P Manual (Anon. 1997).

\section{Pest management thresholds and treatment responses}

Some treatments were recommended based on pest phenology. These included mineral oil at 'green-tip' (early September) for the control of scale insects, and tebufenozide at the start of spring leafroller and codling moth flights and again 14-21 days prior to harvest. In all other instances, growers were requested to monitor for pests and respond with insecticide only if a pest threshold was exceeded. Some of the insecticidal responses were justified on the basis of pest presence in the block during the previous harvest. The thresholds and recommended treatment responses are summarised in Table 1.

TABLE 1: The treatment thresholds and recommended insecticidal responses for orchards following IFP guidelines in the 1997-98 season.

\begin{tabular}{|c|c|c|}
\hline Pest (and time) & Threshold & Products \\
\hline Apple leafcurling midge & $>20 \%$ egg infested shoots & diazinon \\
\hline Codling moth & $\begin{array}{l}\text { Either } 5 \text { moths in a trap in one week } \\
\text { or }>2 \text { moths/trap/week } \\
\text { or } 10 \text { moths in a trap since last spray }\end{array}$ & $\begin{array}{l}\text { tebufenozide } \\
\text { or diazinon } \\
\text { or chlorpyrifos }\end{array}$ \\
\hline $\begin{array}{l}\text { Leafroller (November) } \\
\text { (December on) }\end{array}$ & $\begin{array}{l}\text { Damage in } 50 \text { shoots or } 1000 \text { fruit } \\
>30 \text { moths/trap since Dec } 15 \\
\text { or last spray }\end{array}$ & $\begin{array}{l}\text { tebufenozide }^{1} \\
\text { or diazinon } \\
\text { or chlorpyrifos }\end{array}$ \\
\hline Mealybug (September) & Presence on fruit last harvest & $\begin{array}{l}\text { oil + either } \\
\text { buprofezin }{ }^{1} \text { or } \\
\text { chlorpyrifos }\end{array}$ \\
\hline Mealybug (November) & $>1 \%$ fruit infested last harvest & chlorpyrifos \\
\hline Scale (September) & $\begin{array}{l}\text { Presence on fruit last harvest } \\
>0.25 \% \text { on fruit infested last harvest }\end{array}$ & $\begin{array}{l}\text { oil } \\
\text { oil + either } \\
\text { buprofezin }^{1} \text { or } \\
\text { chlorpyrifos }\end{array}$ \\
\hline Scale (January) & $>1 \%$ on fruit infested last harvest & $\begin{array}{l}\text { chorpyrifos or } \\
\text { diazinon }\end{array}$ \\
\hline Woolly apple aphid & Colonies on $>10 \%$ of shoots & chlorpyrifos \\
\hline
\end{tabular}

${ }^{1}$ preferred treatment 


\section{Pheromone trap records}

Pheromone traps to monitor populations of codling moth and the leafroller, lightbrown apple moth (LBAM, Epiphyas postvittana), were recommended to growers participating in the IFP programme. In Otago some growers also trapped the greenheaded leafroller, Planotortrix octo, and used this additional information in determining their pesticide use. The IFP recommendations suggested the use of one trap for each of these pests per 2 ha of orchard. Codling moth trapping commenced at 'petal-fall' (late October) in all districts. Leafroller pheromone trapping commenced in December, but leafroller control decisions only used trap catch data from mid-December onwards. Traps required regular servicing including reading and clearing weekly, changing bases every three weeks and pheromone caps every six weeks. Trapping for both pests continued until harvest. Growers' trap records were analysed from 215 completed sets of records submitted to ENZAFRUIT nationally.

\section{Harvest assessment procedures}

At harvest, 2000 fruit (200 from each of 10 bins) per cultivar were assessed by consultants in the field for any possible pest damage or infestation. Damaged or infested fruit were brought to HortResearch where the incidence of pests, or damage, was recorded. Ten apple cultivars and 330 cultivar blocks were examined nationally in this assessment programme. This study reports on results from 278 blocks including the cultivars Cox, Gala and Braeburn as these formed the bulk of the sampling programme. Blocks from each district included Waikato $=27$; Gisborne $=19$; Hawkes Bay $=147 ;$ Nelson $=40 ;$ Canterbury $=9$ and Otago $=36$.

\section{Pest control records}

Insecticide use on approximately 550 IFP blocks nationally (Royal Gala and Braeburn only) was determined by analysis of growers' Pest Control Record Books as submitted to ENZAFRUIT. Although pre-bloom insecticides are important for control of certain pests, the regional analysis covered only 'post-bloom' use as this period makes the largest contribution to overall insecticide use. Insecticides applied to each block were classified as Insect Growth Regulators (IGR), particularly tebufenozide and lufenuron, or organophosphates (OP), which included chlorpyrifos, diazinon and restricted use of azinphos-methyl. Carbaryl, which is used for fruit thinning, was excluded from this analysis.

\section{RESULTS \\ Codling moth and leafroller pheromone traps}

Codling moth and leafroller activity in traps is presented for each district in Table 3 and is classified into the percentage of blocks in each district with different levels of moth activity. Codling moth activity was greatest in the Waikato and Gisborne districts with almost $75 \%$ and $68 \%$ of orchards respectively having average seasonal trap catches of more than 20 codling moth. Moderate levels of codling moth activity occurred in Wairarapa and Otago orchards. Codling moth activity was low in Hawkes Bay orchards and least in Nelson where $55 \%$ and $84 \%$ of traps respectively caught 10 or less codling moth all season.

Leafroller pheromone traps in Gisborne showed that a large proportion of orchards captured high numbers of leafrollers suggesting that many properties were exposed to potentially greater risks of leafroller damage than in other districts. A large proportion of orchards in Waikato, Wairarapa and Nelson were also exposed to relatively high levels of leafroller activity while other orchards had low trap catches. This trend in moth activity suggested large within region variation in the potential risk of leafroller damage. A high proportion of traps in Hawkes Bay and Otago orchards had low season-long catches of leafrollers suggesting that the risk of potential leafroller damage in these districts was lower than for other regions. However, in Otago, mating disruption for P. octo may have also contributed to lower overall seasonal trap catches. 
TABLE 2: The percentage of orchards in each district in each category of moth activity.

\begin{tabular}{lcccccc}
\hline $\begin{array}{l}\text { Seasonal } \\
\text { moth catch } \\
\text { per trap }\end{array}$ & Waikato & Gisborne & $\begin{array}{c}\text { Hawkes } \\
\text { Bay }\end{array}$ & Wairarapa & Nelson & Otago $^{1}$ \\
\hline $\begin{array}{l}\text { Codling moth } \\
\text { nil }\end{array}$ & 0 & 0 & 7 & 0 & 25 & \\
$\leq 10$ & 8 & 10 & 48 & 28 & 59 & 25 \\
$11-20$ & 16 & 22 & 18 & 11 & 5 & 38 \\
$21-40$ & 33 & 26 & 10 & 39 & 7 & 19 \\
$40-80$ & 21 & 32 & 15 & 17 & 4 & 12 \\
$>80$ & 21 & 10 & 2 & 5 & 0 & 0 \\
$n$ & 24 & 31 & 82 & 18 & 44 & 16 \\
& & & & & & \\
Leafroller & 16 & 9 & 34 & 0 & 21 & 50 \\
$\leq 50$ & 21 & 0 & 32 & 17 & 33 & 33 \\
$50-100$ & 21 & 12 & 14 & 28 & 15 & 11 \\
$101-150$ & 10 & 24 & 5 & 5 & 6 & 0 \\
$151-200$ & 16 & 21 & 6 & 17 & 6 & 6 \\
$201-250$ & 16 & 34 & 9 & 33 & 19 & 0 \\
$>250$ & 19 & 33 & 80 & 18 & 48 & 18 \\
$n$ & & & & & & \\
\hline
\end{tabular}

${ }^{1}$ In some Otago orchards both lightbrown apple moth and $P$. octo were trapped and the combined information used to determine pesticide use.

\section{Insecticide use under IFP programmes}

The average level of insecticide use in IFP programmes for each district is shown in Table 3. OP insecticide use was highest in Waikato orchards and lowest in Canterbury orchards. Higher levels of OP insecticide use were attributed to regional pest control issues e.g. the elevated pest status of apple leafcurling midge (Dasineura mali) in Waikato, Wairarapa and Nelson orchards and the obscure mealybug (Pseudococcus viburni) in Hawkes Bay. However, average use of OP insecticide was low (range 0.4 - 1.4 applications on Braeburn) and was similar to that reported for Hawkes Bay, Nelson and Otago in the 1996-97 pilot programme (0.5 - 1.5 for Gala, 0.4 - 1.0 for Braeburn, Walker et al. 1997).

TABLE 3: Regional analysis of the average post-bloom OP and IGR insecticide use in IFP programmes operating on two apple cultivars in seven districts.

\begin{tabular}{|c|c|c|c|c|c|c|c|}
\hline & Waikato & Gisborne & $\begin{array}{c}\text { Hawkes } \\
\text { Bay }\end{array}$ & Wairarapa & Nelson & Canterbury & Otago \\
\hline \multicolumn{8}{|c|}{ Royal Gala } \\
\hline OPs & 1.1 & 0.5 & 0.8 & 0.9 & 1.0 & 0.4 & 0.5 \\
\hline IGRs & 3.0 & 3.6 & 2.4 & 2.9 & 2.2 & 2.0 & 2.3 \\
\hline Total & 4.1 & 4.1 & 3.2 & 3.8 & 3.2 & 2.4 & 2.8 \\
\hline . & 32 & 34 & 143 & 9 & 12 & 7 & 33 \\
\hline \multicolumn{8}{|c|}{ Braeburn } \\
\hline OPs & 1.4 & 0.7 & 0.8 & 1.1 & 1.2 & 0.4 & 0.4 \\
\hline IGRs & 4.4 & 4.0 & 3.1 & 4.2 & 2.9 & 2.6 & 2.7 \\
\hline Total & 5.8 & 4.7 & 3.9 & 5.3 & 4.1 & 3.0 & 3.1 \\
\hline$n$ & 30 & 32 & 138 & 19 & 11 & 10 & 38 \\
\hline
\end{tabular}


IGR insecticide use (Table 3) was highest in Waikato and Gisborne which was attributed to exposure of orchards to high levels of codling moth activity in early summer followed by high leafroller activity (Table 2) in mid and late summer. IGR insecticide use was lowest in Canterbury, but use in Hawkes Bay, Nelson and Otago was also low and similar to that reported for the 1996-97 pilot programme (Walker $e t$ al. 1997). The overall level of IGR use ranged from 2.0 - 3.6 applications on Gala and from 2.6 - 4.4 on Braeburn.

\section{Fruit damage at harvest}

The four pests accounting for most fruit loss at harvest were leafroller and codling moth (fruit damage) and either mealybug or scale insect infestation (Table 4). All districts produced fruit crops which were substantially free of leafroller and codling moth damage. Damage from both of these pests was lowest in Waikato and Gisborne orchards where their high activity contributed to higher levels of insecticide use and consequently lower damage. Leafroller damage was below $1 \%$ in more than $96 \%$ of Hawkes Bay and Otago orchards and overall damage by leafrollers was lower than the 1996-97 season. Approximately 14\% of Nelson orchards exceeded 1\% leafroller damage but $2 \%$ was the maximum recorded level of damage. Leafroller larvae were present in samples from $17 \%$ of Nelson and 3\% of Hawkes Bay blocks and resulted in predicted regional infestation rates of 1.5 and 0.3 larvae per 10,000 fruit respectively.

TABLE 4: The average percentages of insect damage to apple crops following IFP pest management recommendations in each district.

\begin{tabular}{llccccc}
\hline District & Cultivar & $\begin{array}{c}\text { Number } \\
\text { of blocks }\end{array}$ & Leafroller & $\begin{array}{c}\text { Codling } \\
\text { moth }\end{array}$ & Mealybug & Scale \\
\hline Waikato & Braeburn & 27 & 0.02 & 0.00 & 0.37 & 0.76 \\
Gisborne & Braeburn & 19 & 0.01 & 0.03 & 0.39 & 2.90 \\
Hawkes Bay & Gala & 45 & 0.20 & 0.05 & 0.31 & 0.01 \\
& Braeburn & 102 & 0.21 & 0.06 & 0.40 & 0.23 \\
Nelson & Cox & 31 & 0.37 & 0.00 & 0.07 & 0.12 \\
& Braeburn & 9 & 0.73 & 0.00 & 0.01 & 1.01 \\
Canterbury & Braeburn & 9 & 0.57 & 0.00 & 0.01 & 0.44 \\
Otago & Braeburn & 36 & 0.16 & 0.03 & 0.00 & 0.56 \\
\hline
\end{tabular}

Low codling moth activity in Nelson and threshold-based treatments in Waikato resulted in no detectable codling moth damage at harvest. Low levels of codling moth damage in Hawkes Bay and Otago orchards were a consequence of low insecticide use.

Control of mealybug and scale insects is highly dependent on pre-bloom insecticide treatments which are not presented here. Mealybugs were detected in fruit assessments from all districts, except Otago (Table 4). Similar average levels $(0.31-0.40 \%)$ of mealybug were detected in North Island crops and $7-11 \%$ of these orchards exceeded fruit infestation levels of 1\%. Maximum recorded levels of mealybug ranged from 4.2 $-4.75 \%$ and some North Island crops exceeded the MAF tolerance for this pest in export apples.

Scale insects were present in a significant proportion of IFP orchards in each district and a few crops were unacceptable for export certification. The principal scale species were San José scale (Quadraspidiotus perniciosus) in Waikato, Hawkes Bay and Nelson; greedy scale (Hemiberlesia rapax) in Waikato, Gisborne and Hawkes Bay; lantania scale (H. latania) in Gisborne and oystershell scale (Quadraspidiotus ostreaeformis) in Otago. Greater than $97 \%$ of Hawkes Bay and Otago IFP blocks had less than $1 \%$ scale infested fruit at harvest. However, in Nelson, Waikato, Canterbury and Gisborne more than $1.0 \%$ of scale infested fruit was found in $8 \%, 24 \%, 25 \%$ and $58 \%$ of IFP blocks respectively. 


\section{DISCUSSION}

Codling moth control with the current IFP guidelines provided a satisfactory response to increasing levels of codling moth risk. High levels of moth activity in Gisborne and Waikato orchards did not lead to increased codling moth damage. The low incidence of codling moth damage in these districts suggested that the current thresholds resulted in timely and appropriate codling moth control responses. The presence of some codling moth damage and a low incidence of fruit infestation in Hawkes Bay and Otago orchards suggested that there is some potential for this pest to inflict damage under current IFP practices, particularly where there are neglected host trees (e.g. apples and walnuts) nearby. However, some damage may be attributed to a small percentage of growers who either did not follow recommendations or failed to interpret thresholds correctly. It will be important to ensure that the low level of codling moth damage detected this season does not increase next season.

Some of the leafroller damage reported in the 1996-97 pilot programme (Walker et al. 1997) could be attributed to growers using tebufenozide below the recommended rate. Increased grower adoption of the recommended rate this season probably contributed to this reduction in damage. This reduction in damage may also be due to the change to pheromone trapping which made monitoring leafroller activity easier for growers. The IFP recommendations generally provided a high level of fruit free of leafroller larval infestation. However, some growers applied just one IGR insecticide instead of the minimum of two recommended under IFP and this accounted for some instances of leafroller damage and larval presence. Higher leafroller activity in Waikato and Gisborne orchards increased tebufenozide use, but damage in these districts was lower than other districts. This suggests that an upward revision of the leafroller threshold (Bradley et al. 1998) may be possible in some regions with no significant increase in leafroller damage.

Mealybug has traditionally been classified as a serious pest in many Hawkes Bay orchards. Its appearance at significant levels in some Waikato and Gisborne orchards suggested that the potential shift in mealybug status under IFP programme was not recognized by growers and consultants implementing IFP for the first time. We anticipate the presence of mealybug will ensure growers implement appropriate mealybug control recommendations next season. The lack of selective insecticides for mealybug control which can be used after flowering remains a significant weakness in the stability of mealybug control under IFP.

Scale insect control under current IFP recommendations proved difficult for some growers in all districts. Infestations occurred in mid and late summer and were frequently associated with shelter trees bordering IFP orchards. If OP insecticide use is to be avoided at this time then additional control strategies are required such as removal or topping shelter or spraying infested shelter trees with an IGR in spring or early summer. New selective insecticides are also under evaluation for scale control in mid-summer.

Fruit produced following the 1997-98 IFP recommendations showed significant improvements over the 1996-97 pilot programme, particularly for leafroller control. Monitoring costs were only slightly lower, but the programme was less demanding of growers and consultants who liked the change to pheromone trap monitoring for leafrollers. Experience this year has shown that technical support is required as NZ IFP-P is implemented by new growers. This was apparent in regions where reduced access to technical backup resulted in some unexpected fruit losses.

\section{ACKNOWLEDGEMENTS}

We wish to acknowledge IFP growers and consultants in each district for their support and cooperation. We thank Lyn Cole and Roger Wallis for technical support. Thanks also to Nicola Park and Amanda Ryan (ENZAFRUIT) for their assistance and national coordination. We would like to acknowledge the financial support of ENZAFRUIT New Zealand (International). 


\section{REFERENCES}

Anon., 1997. New Zealand Integrated Fruit Production - Pipfruit Manual. Published by ENZAFRUIT New Zealand (International), Hastings.

Batchelor, T.A, Walker, J.T.S., Manktelow, D.W.M, Park, N.M., and Johnston, S.R., 1997. New Zealand Integrated Fruit Production for pipfruit - charting a new course. Proc. 50th N.Z. Plant Prot. Conf.: 14-19.

Bradley, S.J., Walker, J.T.S., Wearing, C.H., Shaw, P.W. and Hodson, A.J. 1998. The use of pheromone traps for leafroller action thresholds in pipfruit. Proc. 51st N.Z. Plant Prot. Conf.: (this volume).

Walker, J.T.S., Hodson, A.J., Wearing, C.H., Bradley, S.J., Shaw, P.W., Tomkins, A.R., Burnip, G.M., Stiefel, H.E. and Batchelor, T.A., 1997. Integrated fruit production for New Zealand pipfruit: evaluation of pest management in a pilot programme. Proc. 50th N.Z. Plant Prot. Conf.: 258-263. 